\title{
Is it Time to Adopt Information Technology in Play Therapy?
}

\author{
Aram Lee, ${ }^{1} \mathrm{Mi} \mathrm{Ae} O \mathrm{Oh},{ }^{2}$ Jin Cheol Park, ${ }^{3}$ Se Young Jin, ${ }^{4}$ \\ Ram Hwangbo, ${ }^{1}$ Seong Woo Cho, ${ }^{1}$ and Geon Ho Bahn ${ }^{5}$ \\ ${ }^{1}$ Department of Psychiatry, Kyung Hee University Hospital, Seoul, Korea \\ 2Department of Neuropsychiatry, Seoul National University Bundang Hospital, Seongnam, Korea \\ ${ }^{3}$ Department of Psychiatry, Silverheals Hospital, Namyangju, Korea \\ ${ }^{4}$ Department of Psychiatry, Songchu Mental Hospital, Yangju, Korea \\ ${ }^{5}$ Deparment of Psychiatry, Kyung Hee University School of Medicine, Seoul, Korea
}

\section{놀이치료에서 정보기술을 채택할 때인가?}

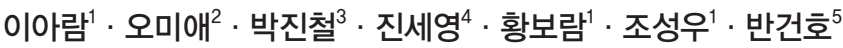 \\ 경희대학교병원 정신건강의학과, ${ }^{1}$ 서울대학교 분당병원 신경정신과, ${ }^{2}$ 실버힐스병원 정신건강의학과, ${ }^{3}$ 송추정신병원 정신건강의학과, ${ }^{4}$ \\ 경희대학교 의학전문대학원 정신건강의학교실 ${ }^{5}$
}

Play therapy, developed by child psychologists, has evolved into a variety of forms. Despite its long history, play therapy is still a valuable therapeutic method for resolving psychosocial challenges. It is used throughout the world and applicable for both youths and infants. Playing itself has both diagnostic and therapeutic values. The toys and patterns of play can manifest the underlying psychological status of children and function as the mediators between therapists and patients. The crucial issue here is that the face-to-face interaction between the therapists and the children is the key to play therapy. Modern society is overloaded with smart technology, such as smartphones, tablet PCs, iPads, and social networking services (SNS). Given the advances in information technology (IT), far beyond what we could have imagined, the current generation is more familiar with iPads or smartphones than with rattle toys or television. Traditional face-to-face interaction has been replaced by SNS communication. This study explores whether the IT environment of computers, smartphones, SNS, or online games can be adapted as a new modality of play therapy and how it could be applied in real treatment settings.

Psychoanalysis 2017;28(2):28-37

KEY WORDS: Psychotherapy · Information technology $\cdot$ Text message $\cdot$ iPad $\cdot$ Play therapy.

Received: February 27, 2017 Revised: March 26, 2017 Accepted: March 31, 2017

Address for correspondence: Geon Ho Bahn, MD

Department of Psychiatry, Kyung Hee University School of Medicine, 23 Kyungheedae-ro, Dongdaemun-gu, Seoul 02447, Korea

Tel: +82-2-958-8556, Fax: +82-2-957-1997, E-mail: mompeian@khu.ac.kr

서 론

놀이는 생각을 언어로 표현하는 것이 부족한 소아에서 의 사소통의 수단이자 삶의 기본 형태이다(Winnicott 1971). 즉, 아동기 놀이란 성인기 사회성 발달과 운동 및 정서발달의 수단이며, 성인기 직업 활동의 준비 과정으로 이어진다. 성 인에서 언어를 매개로 한 정신치료가 이루어지는 것에 비하 여 소아에서는 놀이를 매개로 한 정신치료가 가능하다. 놀이 를 최초로 치료에 사용한 사람은 Hug Hellmuth로 알려져

This is an Open Access article distributed under the terms of the Creative Commons Attribution Non-Commercial License (http://creativecommons.org/licenses/by-nc/4.0) which permits unrestricted non-commercial use, distribution, and reproduction in any medium, provided the original work is properly cited.
있고, 이후 놀이는 소아분석에서 꼭 필요한 기법이 되었다 (Kwak 2000). Klein(1961)은 말로 표현하는 것의 직접적 대 치물로 놀이를 사용하였고, 놀이를 무의식의 상징적 표현으 로 생각하였다. Freud(1945)는 긍정적 관계를 이루기 위해 놀이를 사용하였고, 직접적 해석과 분석적 방법보다는 교육 적 방법이 요구된다고 하였다. 정신분석적 놀이치료에서의 놀이는 허용적이고 비지시적 태도로 관계를 수립하고, 아이 로 하여금 무의식적으로 자유롭게 표현하도록 하며, 갈등을 분석함에 있어 놀이 상황이나 상징을 통해 치료적 해석을 한다(Chung과 Colarusso 2012).

놀이치료에 활용되는 도구나 재료는 시대 흐름에 따라 변 화, 발전되며 다양한 형태로 구성된다. 놀이치료 또는 소아 정신분석 문헌에서 놀잇감을 구체적으로 정의하거나 제한 
한 내용은 거의 없다. 초창기 문헌에서는 놀이치료실 운영에 대한 제한점(limit setting)을 제시하였고, 오늘날도 그 기본 취지는 다르지 않다(Kwak 2000). 즉 치료자를 신체적으로 공격하지 않기, 놀이장비나 시설을 부수지 않기, 면담 시간 외에는 놀이치료실에 머물지 않기, 창밖으로 장난감이나 물 건 던지지 않기, 놀이실 밖으로 장난감 가지고 나가지 않기 등이다. Freud(1945)와 Klein(1961)은 1920년대 초 놀이치료 실에 종이와 연필, 장난감 동물 및 인형, 찰휽 등을 비치하여 치료에 이용하였다. Winnicott(1971)는 종이 위에 구불구불 한 선을 그려 아이들이 선을 추가하면서 그리기에 참여하도 록 권하고, 그 결과물에 대해 자유롭게 이야기하는 스퀴글 게임(squiggle game)을 개발하였다. 이 방법은 소아와 청소 년들의 평가 및 치료에 창의적이고 유용하게 이용할 수 있 으며, 지지적 관계에서는 이 게임을 통해 아이가 현재 겪고 있는 감정적 어려움을 표현하게 만들 수 있고, 궁극적으로 상호 소통의 문을 열어주는 역할을 기대할 수 있다. 이후 학 파에 따라 또는 놀이 기법의 형태에 따라 다양한 형태의 놀 이치료기법이 도입되었다.

21세기는 사회연결망(social networking service, SNS)의 시대이다. 1995년 www(world wide web), 2000년 인스턴트 메시징(instant messaging), 2004년 페이스북(Facebook), 2007년 트위터(Twitter)가 개설되면서 SNS는 계속 진화하고 있다(Plowman과 McPake 2013). 2010년에 태어난 아이들 은 아이패드 $(\mathrm{iPad})$ 가 출시된 해에 태어났으며, 컴퓨터, 휴대 전화 등 디지털 기기, 즉 정보기술(information technology, IT)에 둘러싸여 성장한 세대, 디지털 원주민(digital natives) 이라고 불린다(Prensky 2001). 그들은 모유 수유를 할 때부 터 IT에 노출된다. 영아는 12 개월 전후 시기에는 스마트기기 를 새로운 놀이 또는 전화기로 인식하고 탐색 위주의 활동을 하며, 24개월 전후 시기에는 스마트기기를 주도적으로 조작 하면서 조작 기능을 빠르게 습득한다(Roh 등 2016). 바비인 형으로 대표되는 장난감이 스마트폰 속 포키몬(Pokemon)으 로 대체된 것이다.

전통놀이치료에서는 아이들의 생활의 일부인 '장난감'을 치료실에서 활용하였다. 디지털 시대의 아이들에게 익숙한 생활의 일부이며 놀잇감인 IT 기기 역시 고전적 장난감과 함께 놀이치료에 활용할 수 있을 것인지, 즉 디지털 원주민

a놀잇감은 문헌마다 장난감(toy), 물체(object), 놀잇감(plaything), 놀 이자료(play materials) 등 맥락에 따라 사용되는 의미가 다를 수 있 다. 본 연구에서는 놀이용으로 제작된 상품화된 놀잇감 이외에 생활 용품, 자연물 및 성인들이 제작해 주는 교재 - 교구 등 유아들이 놀 이에서 사용하는 모든 것들을 '놀잇감'으로 정의한다(Park과 Ohm 2010).
인 영유아 및 소아청소년 환자와 비디지털 세대(non-digital generation)인 치료자 사이의 격차를 치료실에서 어떻게 다 룰 것인가에 대한 고민이 필요한 시점이다. 따라서 본 논문 에서는 IT 개념과 관련 문화 및 의학 영역의 자료를 검토하 여 놀이치료와 IT 문화의 접점을 찾아보았다.

\section{본 론}

본 연구에 필요한 자료는 다음과 같은 경로로 수집하였다. PubMed, Google Scholar, Pep-Web, Scopus, 학술연구정보 서비스(Research Information Sharing Service, RISS), The Institute of Electrical and Electronics Engineer(IEEE), Amazon에서 자료를 검색하였다. 검색 단어는 놀이치료, 기술정 보(intelligence technology), SNS, 스마트폰, 아이패드(iPad) 등이었다. 일부 자료는 검색 과정에서 찾은 논문이나 단행 본, 보고서 등에서 알게 되었으며, 그 경우 개별적으로 추가 확인하여 작업하였다. 언어는 영어 혹은 한국어로 쓰여진 자 료로 제한하였다.

놀이치료와 IT 문화에 대한 논의를 전개하기 위해 네 가지 주제로 나누어 살펴보았다. 먼저, IT 관련 용어와 IT 문화의 변천에 대하여 기술하였다. 이어서 정신건강의학과 영역은 물론 의료계에서의 IT 문화가 구현되고 있는 현황을 알아보 았다. 또한 현대 사회에서 IT 문화는 필수불가결이며 많은 순기능을 발휘하고 있으나, 영유아 및 소아청소년 세대에 끼 치는 역기능에 대해 언급하였다. 끝으로 본 연구의 핵심주제 인 놀이치료에 IT 문화를 접목할 것인가에 대한 답을 구하고 자 하였다.

\section{IT 문화의 발전과 확산}

\section{IT 관련 용어 정의}

'기술(technology)'은 인간의 능력을 증진시키는 기술과 과학적 지식을 뜻하는 단어로 흔히 집이나 교육 환경에서 볼 수 있는 전자제품을 가리키는 말로 쓰인다(Plowman 등 2010). IT는 업무용 데이터, 음성 대화, 사진, 동영상, 멀티미 디어는 물론 아직 출현하지 않은 형태의 매체까지 포함하며, 정보를 개발, 저장, 교환하는 데 필요한 모든 형태의 기술까 지도 망라한다(Hoffman 2013). 아이들의 환경에서 마주할 수 있는 IT 기기는 텔레비전, DVD players, 전자 음악 장치 인 아이포드(iPod), $\mathrm{CD}$ 플레이어, 스마트폰, 스마트폰 카메 라, 아이패드, 데스크탑 컴퓨터, 랩탑 컴퓨터, 타블렛 $\mathrm{PC}$, 닌 텐도 플레이스테이션과 같은 게임기기 등이 있다. Tapscott (1998)은 저서 'Growing up digital'에서 2세부터 22세 사이 
의 집단을 'Net generation( $\mathrm{N}$-generation, $\mathrm{N}$-geners)'이라고 정의하였다. 이들은 디지털 미디어와 인터넷에 둘러싸여 자 라난 세대이다. Prensky(2001)는 디지털 기술과 함께 자라 고 인터넷, 컴퓨터, 비디오 게임 등의 언어를 사용하는 '원어 민(native speakers)'들을 '디지털 원주민(digital natives)'이라 고 정의하였고, 성인이 된 후에 IT를 받아들여 습득한 계층 은 '디지털 이민자(digital immigrants)'로 차별화하였다. 청 소년은 '디지털 젊은이(digital youth)'로 불리기도 한다(Subrahmanyam과 Smahel 2011).

\section{IT 문화의 확산}

2013년 기준 최다 방문 SNS는 페이스북(Facebook)으로 7 억 5천만 명이 방문하였고 다음으로는 2억 5천 900만 명이 트위터(Twitter)를, 3 위는 주로 전문가 집단인 18세 이상의 사용자들로 구성된 1억 1천만 명이 방문한 링크인(LinkedIn) 이었다(Saleh 등 2014). 2013년 전 세계에서 페이스북 가입자 수는 12 억 300 명이다. 방문자 수 1 위를 차지한 페이스북은 만 13세 이상이 사용 가능하도록 나이제한이 있으나, 미국 소비자 대상 조사 보고서에 따르면 페이스북 사용자의 5 백 만 명 이상이 10 세 미만이며, 부모의 지도감독 없이 자녀들이 페이스북 계정을 사용하고 있다(Saleh 등 2014). 청소년들은 인터넷을 기반으로 한 소셜미디어를 이용하여 대화하고 관 계를 형성하고 그들의 정체성을 탐험한다(Subrahmanyam 과 Greenfield 2008). 미국 소아과학회(Strasburger 등 2013) 에서 십대 청소년들의 스크린 노출시간을 하루 2 시간 이내 로 권장하고 있음에도 불구하고, 미국 십대들은 하루 6시간 이상을 스크린 앞에서 보낸다(Kenney와 Gortmaker 2017).

우리나라의 경우 2016년도 인터넷 이용 실태 조사에 따르 면 만 3 세 이상 인구 중 $88.3 \%$ 가 인터넷 이용자로 5년 전에 비해 $10.3 \%$ 증가하였다(Korea Internet and Security Agency 2017). 연령대별로는 3 9세가 82.9\%, 10대 및 20대는 100\%, 30 대가 $99.8 \%$ 이며, 60 대도 $74.5 \%$ 였다. 주 평균 인터넷 이용 시간은 전체 평균 14 시간 17 분이었다. 스마트폰 보급률은 전 체 가구의 $88.5 \%$, 가구원의 $85.0 \%$ 였고, 스마트폰 이용자의 $91.8 \%$ 가 하루 한 차례 이상 사용하였다. 남성 이용률은 $91.0 \%$, 여성은 85.6\%였다(Korea Internet and Security Agency 2017). 3 5세의 유치원 자녀를 둔 엄마들 대상 연구에서는 유아의 스마트폰 사용이 주 1 2회가 40.7\%였으며, 엄마의 스마트폰 중독 정도와 유아의 사용빈도가 상관을 보였다 (Kim과 Moon 2015). 수도권 어린이집에 등원 중인 3 5세 유아부모 대상의 설문 조사에서 최초의 스마트폰 사용 시기 는 만 1 2세가 가장 많았고(37.7\%), 사용빈도는 주 1 2회 (35.4\%)였으며, 주 사용목적은 $73.9 \%$ 가 동영상 시청이었다
(Roh 등 2016).

\section{놀이와 IT 문화}

장난감의 역사는 고대 그리스 때부터 시작되었을 것으로 추정하며, 기원전 2000년경 이집트, 고대 그리스, 로마시대 의 유물에도 인형, 목마, 공, 소꿉놀이 도구, 동물을 본뜬 놀 잇감 등이 있어 장난감의 역사가 꽤 오래 되었음을 알 수 있 다(Burton 1997). 이후 시대에 따라 다양한 장난감이 등장하 였으나 장난감의 기능과 개념은 크게 바뀌지 않았다. 그러나 IT 시대에 접어들면서 장난감의 개념은 매우 빠르게 변하고 있으며, 세대 간 차이는 더 빠르게 변하며 크게 벌어지고 있 다. IT는 모든 연령의 아이들의 놀이에서 큰 역할을 차지한 다. 아이들은 많은 시간을 텔레비전, 컴퓨터 스크린 앞에서 보내고 밖에서 뛰어 노는 시간은 줄어들었다(Subrahmanyam과 Šmahel 2011). 이처럼 영유아기부터 형태가 있는 장 난감을 경험하기보다는 스크린을 통해 놀이를 경험하게 된 다. 아이들이 놀잇감이라고 생각하는 컴퓨터, 스마트폰, 텔 레비전 등에 사용하는 '스크린시간(screen time)'이 모두 놀 이시간이고, 그러한 기기들을 장난감으로 여기는지 짚고 넘 어갈 필요가 있다. 최근 스크린시간과 어린이 비만 혹은 과 도한 몰입 증상(Brown 등 2017)과의 정적 상관에 대한 연구 가 늘고 있는 이유도 마찬가지이다. 우리나라 12 18세 남녀 학생을 대상으로 한 비만과 스크린시간의 상관성 연구(Chung 등 2010)에서 학생들의 일 스크린사용시간이 4.3시간으로 나 타난 점은 스크린시간의 용도에 대한 분류나 정의가 필요함 을 알 수 있다. 초중고등학생과 대학생을 대상으로 한 사이 버 환경에 대한 인식도 조사에서 대상군의 $96.9 \%$ 가 집에 컴 퓨터가 있고, 초등학생에서 대학생으로 가면서 사용시간도 늘어나며, 사이버 공간을 재미있는 놀이공간으로 인식하고 있었다(Park 등 2011).

이처럼 급변하는 IT 기기는 생활도구와 장난감, 놀이도구 의 경계를 나누기 어려울 정도로 영유아기부터 생활과 밀접 한 관계를 맺고 있다. 이러한 점에서 오늘날 영유아는 IT 의 존형 발달과정(IT-dependent development)을 거치게 될 것 으로 예상된다.

\section{의료계에서 IT 문화의 확산}

IT 기기를 가장 생산적으로 활용하는 분야 중 하나가 의 료계이다. 원격진료를 포함하여 비디오 게임의 원리를 이용 한 로봇수술까지 이미 다양한 임상 영역에서 상용화되고 있 다(Table 1).

정신건강의학과 분야에서의 IT 기기 활용은 빠르게 늘고 있다. 6 주 동안 114 명에게 스마트폰을 이용하여 감정, 스트 


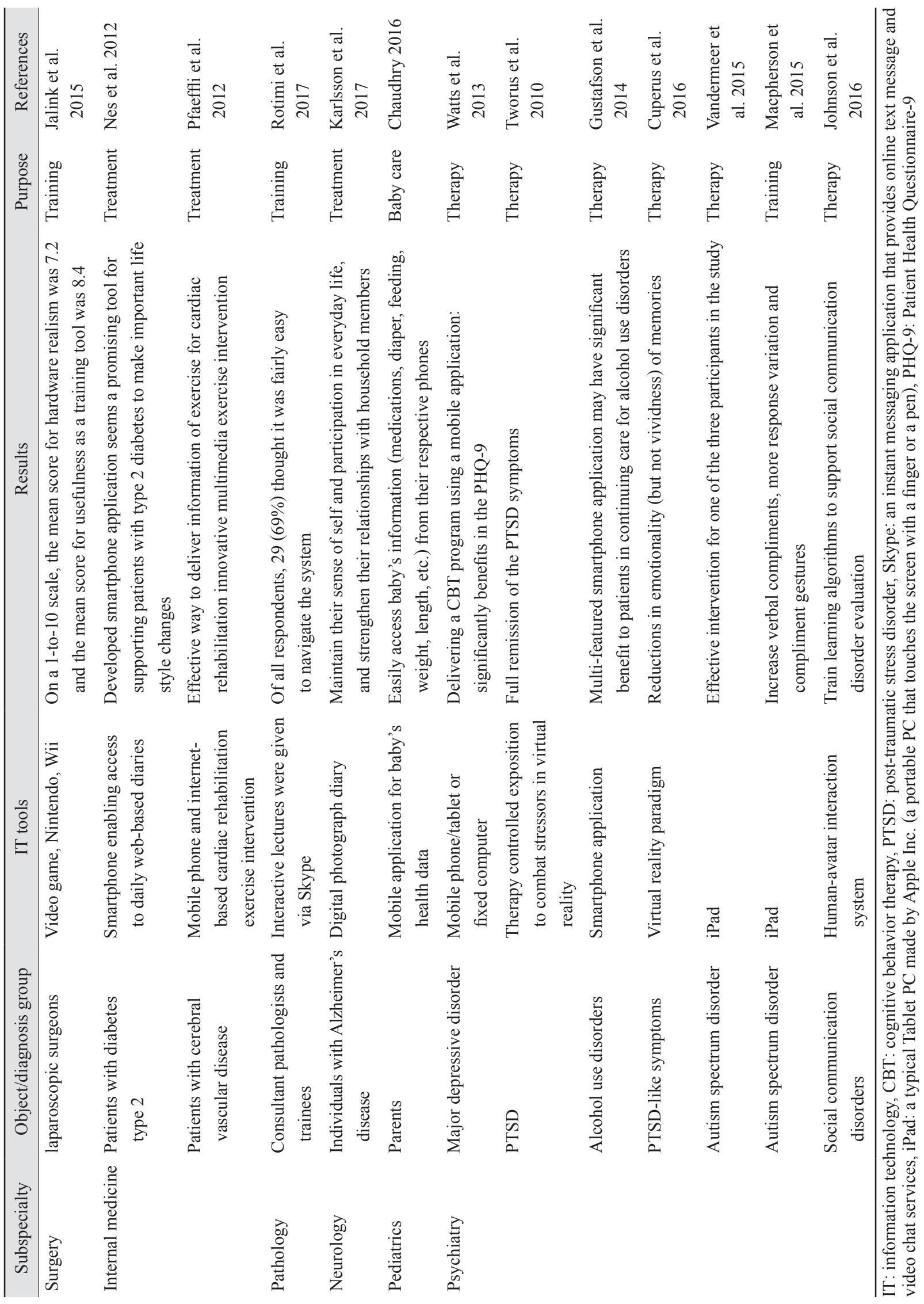


레스, 대처 양식을 스스로 관찰 및 기록하도록 교육한 결과, 자기 감정 인식이 향상되었고 그에 따라 우울증상이 경감되 었다(Kauer 등 2012). 35명의 우울증 환자에게 컴퓨터, 휴대 폰, 아이패드를 이용한 인지행동치료 프로그램 시행 후, 3 개 월간 추적 평가에서 세 가지 기기 사용자 모두 우울증상이 유의하게 호전되었다(Watts 등 2013). 알코올사용장애 환자 들을 대상으로 8 개월간 치료 개입 후, 4 개월간 추적 검사에 서 스마트폰 앱을 사용한 중재가 알코올사용장애의 지속 치 료에 도움을 줄 수 있는 것으로 나타났다(Gustafson 등 2014). 불안증, 공황장애, 외상후스트레스장애 등과 같이 실 생활에서 위축을 보이는 경우 행동 수정을 위해 사용되는 가상현실기법(Tworus 등 2010), 정서기억을 감소시켜 증상 을 완화시키는 기법(Cuperus 등 2016) 등도 모두 IT 발전과 더불어 진행되고 있다. 정신과에서 유용한 평가 척도인 자기 보고식 진단 검사 도구도 과거 지필검사 방식에서 IT 기기 를 이용하는 경우가 늘고 있으며(Torous 등 2015), 검사 수 용도 및 만족도도 높아지고 있다(Campbell 등 2017).

소아청소년 정신과 분야에서는 특히 자폐 아동을 대상으 로 아이패드를 이용하여 사회기술 훈련과 스토리텔링에 활 용하였다(Vandermeer 등 2015). 54명의 6세 이하 자폐 아동 을 성별 및 연령에 따라 무작위로 두 군으로 나누어 아이패 드 효능을 비교 검토하였다. 사회의사소통훈련에 아이패드 사용의 효과는 두드러지지 않았지만, 참가자들의 기계 사용 방식에 대한 긍정적 태도는 앞으로 이러한 기기 사용이 유 익할 것임을 시사한다. 다섯 명의 자폐 아동에게 또래나 부 모들이 아이패드로 축구 게임을 하는 것을 구경하도록 하고, 아이들의 태도나 말을 관찰한 결과, 비디오 게임을 관찰한 아이들의 언어적 표현이나 행동이 증가하였다(Macpherson 등 2015). 소통기능에 매우 중요한 합동주시 관련 평가 및 훈 련 프로그램은 자폐증 및 사회적 의사소통장애(social communication disorder) 등의 증상 개선에 기여할 것이다(Caruana 등 2017). 또한, 정서 아바타(affective avatar)를 통해 사회적 의사소통장애 환아를 평가하고 지원하고자 아바타 기 반 대화형 응용 프로그램이 개발 중이다(Johnson 등 2016). 이를 통해 사회적 의사소통장애의 사회적 기술, 공감 및 감정 관리, 자신에 대한 이해를 향상시킬 수 있으리라 기대된다.

정신의학은 물론 의료계 전반에서 IT 활용은 매우 활발하 게 진행되고 있다. 당뇨병(Nes 등 2012)이나 심혈관계 질환 자(Pfaeffli 등 2012)에게 스마트폰이나 인터넷 등의 IT 기 기 활용은 이미 오래 전부터 시작되었고, 현재는 다양하게 확산된 상태이다. 비디오 게임을 외과의사들의 복강경 수술 기법 습득에 활용하기도 하며(Jalink 등 2015), 스카이프 (Skype)를 통해 영국과 나이지리아 사이에 조직병리 연수를
시도할 수 있는 것도 IT 기기 덕분이다(Rotimi 등 2017). 또 한 조기치매 환자들에게 기억력 향상과 소통방법 개선을 유 도하는 디지털 사진일기(Karlsson 등 2017), 아이의 섭취 및 배설량, 감염 및 투약 현황 등 건강 정보를 기록하고 관리하 도록 해주는 어플리케이션 역시 IT 기술의 좋은 활용 예이 다(Chaudhry 2016).

\section{IT 문화의 역기능}

새로운 치료법이 개발되면 임상에 도입하기 전, 치료 효과 외에도 부작용 및 안전성 평가가 필요하다. SNS가 외로움과 우울감을 조절하며 자존감 상승, 사회적 지지, 전반적 안녕을 증가시키는 수단이 된다는 IT 기기의 순기능과 긍정적 측면 도 있으나, 역기능에 대하여 고려하지 않을 수 없다(O’Keeffe 등 2011). IT 기기나 SNS의 사용이 정신건강에 악영향을 끼 친다는 연구 결과도 이어지고 있기 때문이다. 장시간 SNS 사용은 정신건강에 나쁜 영향을 미칠 수 있고, 정신건강 수 준이 낮은 사람에서 건강하지 못한 SNS 사용행태가 나타날 수도 있다.

\section{인터넷 및 스마트폰 중독}

Goldberg(1996)가 인터넷중독장애(internet addiction disorder)라는 용어를 사용하면서 인터넷 사용의 질병 개념이 부각되었다. 과도한 인터넷의 사용은 개인의 심리적, 정신 적, 사회적으로 부정적인 영향을 미칠 수 있다. 병적으로 인 터넷을 사용한 사람들의 경우 우울감, 외로움이 증가하며, 학생들의 경우 학업 성적이 떨어지고 집중력을 저하시킬 뿐 아니라 가정 내에서 또는 교우 관계에서 갈등 및 마찰을 일 으킬 수 있다(Männikkö 등 2015). 2015년 인터넷(스마트폰) 과의존 실태조사에서 보고된 바에 따르면 우리나라 만 3 59 세 인터넷 이용자 중 인터넷 과의존 위험군 수는 5,810천 명 (16.2\%)이었다(National Information Society Agency 2015). 연령별 과의존 위험 현황을 살펴보면, 3 9세 $12.4 \%, 10$ 대 $31.6 \%, 20$ 대 $24.2 \%, 30$ 대 $14.5 \%, 40$ 대 $10.7 \%, 50$ 대 $5.3 \%$ 로 소아청소년군이 성인층보다 높았다. 문제가 되는 스마트폰 사용자(problematic smartphone user, PSU)에 대한 연구 (Elhai 등 2017)에서는 스트레스, 불안, 우울과 같은 정신병 리가 과도한 스마트폰 사용에 영향을 미칠 수 있음을 시사하 였고, 대규모 중국 대학생 집단의 PSU 유병률 연구에서 대 상군의 21.3\%가 PSU 진단에 부합하였다(Long 등 2016). 인 터넷 이용률이 높아지고 인터넷의 접근 수단인 스마트폰의 대중화로 중독 및 중독 위험군 비율이 높아져 정신질환 진 단 및 통계 편람 제5판(Diagnostic and Statistical Manual of Mental Disorders fifth edition, DSM-5)에는 인터넷게임장 
애(internet gaming disorder)가 ‘향후 연구가 필요한 질환’ 후 보로 등재되었다(American Psychiatric Association 2013).

인터넷, 스마트폰 사용이 소아청소년에게 미치는 영향에 대한 연구는 충분하지 않다. 물질 중독과 유사하게 내성과 금단 증상이 나타나며 물질 중독에서 나타나는 뇌구조의 변 화와 동일하게 전두엽의 기능과 구조를 변화시킨다(Kuss와 Griffiths 2012). 일반적으로 주의력결핍과잉운동장애(attention-deficit/hyperactivity disorder, ADHD) 아동이 일반 아 동에 비해 인터넷게임 등에 쉽게 몰입하는 것으로 알려져 있 지만, 최근 연구에서는 인터넷게임장애가 있는 $\mathrm{ADHD}$ 군과 $\mathrm{ADHD}$ 만 있는 군의 양적 뇌파(quantitative electroencephalography) 검사상 $\mathrm{ADHD}$ 환자들이 인터넷 게임을 통해 오 히려 뇌기능 활성화를 꾀한다는 결과를 보고하였다(Park 등 2017). 즉, 같은 인터넷 게임을 하더라도 게임중독 상태와 건 강한 IT 기기 활용을 구분할 필요가 있음을 시사한다.

\section{공격성 및 범죄 관련}

스마트 미디어가 가지는 특성 중 하나는 가상 현실에서의 소통이라는 점이다(Männikkö 등 2015). 가상 의사소통의 익명성은 마치 셀 수 없이 많은 친구들 집단의 일원이 되는 것과 같이 아이들을 흥분시키고, 현실 세계와의 실제적 관계 는 제쳐 두게 만든다. 이러한 현실과 가상현실 사이에서의 혼 동은 현실에서의 친밀한 관계 형성의 양적, 질적 수준 저하 를 가져올 수 있다. Whang과 Chang(2004)은 최대 온라인게 임인 리니지(Lineage)를 이용하는 사람들이 가상현실 속에 서 새로운 정체성을 형성하고, 반사회적 행동 경향을 보일 수 있음을 경고하였다.

인터넷의 특성인 개방성과 익명성은 사이버상 폭력 및 성 관련 범죄 증가에 기여하고 있다. IT 기기의 보급 확산과 함 께 사이버폭력의 피해자는 $56 \%$ 까지 증가했다고 하며, 피해 자들은 사회 불안, 심리학적 부담, 우울증상 또는 공격 성향, 불충분한 분노 조절, 학교에서의 문제 행동을 보인다 $(\mathrm{Ju}-$ vonen과 Gross 2008). 사이버폭력 피해 아동들은 청소년기 에 우울증이나 만성 신체 통증을 호소하는 비율이 높아진다 (Selkie 등 2016). 미국 내 온라인 성문제에 대한 2000년, 2005 년, 2010년의 비교 조사에서 10 17세 청소년 중 원치 않는 성적 유혹을 경험한 빈도가 $19 \%, 13 \%, 9 \%$ 로 낮아지는 추세 를 보였다(Jones 등 2012). 하지만 포르노 영상 노출 빈도나 성희롱 같은 세부 항목에서는 여전히 증가 추세를 보이며 특히 여학생들의 피해가 늘고 있다. 네덜란드의 남녀 청소년 과 성인을 대상으로 한 음란문자(sexting) 상황 조사에서 성 인 남녀 및 남자 청소년에 비해 여자 청소년이 SNS상에서 자 신의 신체노출 사진을 보내고 음란문자 교신으로 이어지는
비율이 유의하게 증가하였다(van Oosten과 Vandenbosch 2017).

\section{IT 문화와 놀이치료}

영유아 및 소아청소년 정신건강 영역에서 놀이는 진단과 치료의 두 가지 기능을 한다. 놀이를 통하여 아동의 사고와 감정의 상태를 포괄적으로 파악하는 진단적 가치가 있고, 아 동의 문제점과 심리적 갈등이 놀이를 통하여 표현되며 재경 험될 수 있다는 점에서 치료적이다(Kwak 2000). 이러한 놀 이치료에서 장난감을 사용하는 것은 유용한 보조도구가 될 수 있다. 그러나 디지털 세대 아이들은 고전적인 장난감을 가 지고 치료자와 함께 노는 것이 불편하며, 자신이 평소 가지고 놀던 전자게임을 가져오거나 치료자의 컴퓨터를 이용하여 치료자와 노는 것을 편하게 느낄 수 있다(Chung과 ColarusSO 2012). 놀잇감의 변화는 단순한 장난감의 변화가 아니고, 놀이치료의 치료적 효과는 물론 의료환경에도 심각한 영향 을 미칠 수 있다. 즉, 과거에는 치료실에 찾아오는 아이들이 바비 인형이나 장난감 권총을 들고 온다고 해서 치료자가 장난감에 대해 연구한다거나 환아의 부모에게 장난감에 대 한 교육을 할 필요가 없었다면, 디지털 이민자인 치료자 세 대는 디지털 원주민 세대인 소아청소년 환자를 치료하기 위 해 IT 기기에 대한 지식 습득을 통해 부모들에게 IT 기기가 미치는 정신건강의학적 영향에 대해서도 설명해 줄 수 있 어야 하고, 놀이치료실에서 IT 기기를 사용하는 것이 치료 경과에 어떻게 영향을 미칠 것인지 예측할 수 있을 것이다.

\section{IT 문화가 아동기 발달에 미치는 영향}

IT 기기 이전에는 아동 발달에 영향을 줄 수 있는 기계가 텔레비전이었고, 텔레비전 시청 시간이 어떠한 영향을 미칠 것인가에 관심이 많았다. 미국소아과학회에서는 특히 2세 이하 영유아에게 텔레비전을 비롯한 미디어 노출이 긍정적 교육 효과가 있다는 주장은 근거가 부족하며, 오히려 부정적 영향이 우려되고, 영유아가 있는 가정에서 부모의 미디어 사 용도 좋지 않은 영향을 미칠 것이라고 주장하였다(Council on Communications and Media 2011). IT 기기와 텔레비전 은 스크린을 사용한다는 공통점이 있으나 컴퓨터나 스마트 폰의 스크린과 텔레비전의 스크린 기능은 차이가 있다. 텔레 비전은 시청자가 스크린 속 인물과 직접 소통할 수 없지만, 스마트폰이나 아이패드의 스크린은 사용자와 상대방의 상 호 작용과 소통이 가능하므로, 함께 하는 놀이의 기능을 갖 추고 있다(Sosa 2016).

IT 기기 관련 놀잇감과 영유아 발달의 관련성을 평가하는 연구가 최근 늘고 있다. Roseberry 등(2014)은 24 30개월 
영유아 36명을 대상으로 어떠한 스크린 미디어 형태가 언어 발달에 유익한 소통방법인가에 대해 처음으로 보고하였다. 다음과 같이 세 군, 즉 실제 상호작용군, 스카이프(Skype)를 이용한 실시간 소통군, 녹화된 비디오를 보면서 소통하는 군 으로 나누어 눈동자 움직임을 추적하고 언어발달 정도를 측 정한 결과, 스카이프 이용군과 실제 상호작용군의 언어 습득 효과가 녹화된 비디오를 이용한 군에 비해 유의하게 높았다. 이는 언어 습득에 있어서 사회적 상호작용이 필수적임을 시 사한다. Sosa(2016)는 IT 관련 놀잇감과 전통놀잇감과의 비 교를 통해 어떤 장난감이 아동의 소통능력 발달에 더 도움 을 줄 수 있는지 검토하기 위해 세 가지 놀잇감을 사용하였 다. 첫째, 아기용 장난감 노트북컴퓨터(baby laptop), 아기용 휴대폰(baby cell phone), 말하는 농장(talking farm) 등의 전 자기기 장난감, 둘째, 나무로 만든 목재 동물모형이나 블록 등의 전통적 장난감, 셋째, 입체감 있는 책을 포함한 그림책 위주의 책 장난감 등으로 모두 동물이름, 색깔, 모형을 배우 는 내용에 대한 것이었다. 그림책을 좋아하지 않는 아이는 전통적 장난감을 이용하여 놀이를 진행하였다. 생후 10 16 개월 아기와 부모 사이에 이들 장난감을 이용한 언어 습득 효과에 대한 평가에서 전자기기가 효율이 가장 낮았으며, 전 통적 장난감과 책 장난감을 이용할 때 긍정적 결과를 얻었 다. 이는 특히 언어발달 초기 유아에서는 IT 기기보다 직접 상호작용이 가능한 놀잇감이 언어발달은 물론 애착 형성에 유용함을 보여주는 결과이다.

영유아 및 소아에서 비디오 게임이나 IT 기기 사용의 긍 정적 측면에 대한 연구는 시작 단계에 불과하지만, 인지, 동 기유발, 정서, 사회성 등의 영역에서 비디오 게임이 갖는 성 과에 대한 연구가 진행 중이다(Granic 등 2014). 첫째, 게임 의 종류에 따라 총을 쏘는 등의 액션 게임은 공간 능력을 발 달시키고, 퍼즐 게임은 문제 해결 능력을 발달시키며 나아가 창의력 향상을 도모하는 등 인지 발달에 긍정적인 영향을 미친다. 둘째, 비디오 게임은 성공에 대한 긍정적인 피드백 과 실패를 통해 동기를 부여한다. 셋째, 비디오 게임 단계마 다 변화하는 환경과 조건에 적응하는 과정에서 감정 조절 능력이 향상된다. 넷째, 친사회적인 비디오 게임을 하는 것 은 친사회적인 행동으로 연결된다.

이러한 기기 사용의 효과 또는 부작용 여부를 결정하는 요인 중 관련 연구자들이 공통적으로 주장하는 것은 스크린 사용 시간이다. 학령기 아이들에게 몇 시간 정도 스크린 기 기 노출을 허용할 것인가에 대해서는 여전히 논란이 있으나 다음 연구결과가 지표가 될 수 있다. 7 11세 아동 2,442명을 대상으로 한 대규모 연구에서 비디오 게임을 주 2시간 미만 으로 제한하고 있는 아동의 경우 과몰입 아동에 비해 시각운
동 기술이 향상되는 긍정적 효과를 보였다(Pujol 등 2016). 반대로, 주 9 시간 이상 게임을 하는 아동은 1 년간 장기간 추 적 관찰 시 품행장애 관련 행동문제와 뇌자기공명영상검사 상 기저핵 회로 변화가 발견되었다. 따라서 아래와 같은 소 아 건강 전문가 집단의 의견을 신중하게 반영해야 한다. 미 국소아과학회는 2세 미만 소아를 텔레비전을 포함한 스크린 에 노출되지 않도록 할 것을 권고하였고, 초등학생의 경우에 는 하루 스크린 노출시간을 두 시간 이내로 제한하도록 하 였다(Strasburger 등 2013). 우리나라 정신건강의학과 전문 의를 대상으로 한 설문 조사에서는 자신들의 자녀가 스마트 폰을 사용하기에 적정한 시기를 평균적으로 중학교 2학년으 로 생각한다고 보고하였다(Lee 등 2015). 홍콩 자치구 보건 부가 발표한 전자기기 사용 지침은 우리나라 전문의 의견과 유사하게 초등학교 졸업 이후 스마트폰을 소유하도록 권고 하였으며, 만 18세까지는 최대한 장기간 전자기기 사용을 피 하도록 권하고 있다(Student Health Service 2014).

\section{놀이치료 시 IT 기기 사용 사례}

저자들은 IT 기기를 아동의 놀이치료 또는 정신분석에 활 용한 논문을 Pubmed, Google Scholar, Scopus, Psychoanalytic Electronic Publishing(pep-web)을 통해 검색하였으나, 단지 세 건의 보고를 확인할 수 있었다(Table 2). Zelnick (2005)은 두 명의 소아청소년 사례를 보고하였다. 초등학교 1 학년부터 3학년까지 치료받았던 스티븐은 부모가 이혼 후 각각 재혼을 하였으며 새로운 자녀를 가진 환아로 치료자와 함께 공공의 적에 대항하여 싸우는 컴퓨터 게임을 했다. 게 임 속에서 환아는 치료자와 함께 적으로부터 승리할 수 있 도록 치료자를 돕기도 하며, 말로는 표현하기 어려운 공격성 과 전투적인 기분을 쉽게 드러냈다. 게임을 하면서 치료자와 환아는 나란히 옆에 앉아 같은 스크린을 공유하면서 신체적, 정서적으로 친밀감을 도모할 수 있었다. 이는 마치 성인 분 석치료에서 카우치와 같은 역할을 하였다. 두 번째 사례인 중학생 알란은 똑똑하지만 사회적 기능이 부족한 남아로 치 료 시간에는 예의 바르고 정직한 소년이었으나 치료에는 방 어적이었다. 치료시간에 채팅방에 접속하여 다른 사람들과 대화 시에는 공격적이고 거친 말투를 사용하며, 치료자에게 반응하는 방법에 대하여 묻기도 하였다. 치료자는 환아의 채 팅 시 태도를 통하여 환아의 문제를 확인하고 적절한 조언 을 함으로써 환아를 도울 수 있었다. Gensler(2011)는 생후 7 개월에 베트남에서 미국으로 입양된 14세 소녀의 치료경과 를 보고하였다. 아홉 살 때 양어머니가 암으로 사망하였고, 13세에 양아버지가 새어머니와 결혼한 뒤 말수가 줄고 감정 표현도 하지 않게 되었다. 치료 초반에는 환아가 직접적인 
질문을 받고 대답하기를 어려워하여 주변적인 이야기만을 주제로 면담하였지만, 이후 치료 시간에 환아가 가져온 노트 북으로 온라인 문자전송 프로그램을 통한 채팅을 시도하였 다. 채팅을 하며 환아는 이전까지 표현하지 않았던 새어머니 에 대한 적개심을 표현하기 시작하였고, 말로 대화할 때 보 다 감정 표현이 늘어났다. 이후 블로그 활동, 창조적 글쓰기 등을 통하여 부모와의 관계뿐만 아니라 친구들과의 관계가 호전되었다. 고통스러운 외상에 압도되어 나약해진 감정을 조절하는 데 문제가 있던 소녀는 사이버 공간에서 디지털 기기를 이용해 자신의 우월함을 키워 나가는 연습을 할 수 있었다. Chung과 Colarusso(2012)는 9세 소녀의 정신분석적 놀이치료 시간에 전통적 정신분석 기법 대신에 아동이 선호 하는 익숙한 소통 수단인 컴퓨터와 인터넷 사용을 통하여 자신의 갈등, 부모 문제, 발달 관련 주제 등을 분석가와 공유 하였다. 분석 초기에는 인형이나 다른 장난감을 사용하였으 나, 치료 수개월 후부터 아이가 자신이 좋아하는 드라마나 블로그 등에 대해 이야기하면서 분석가의 면담실 컴퓨터를 사용하게 해달라고 조르기 시작하였다. 분석가는 자신의 지 도감독자와 상의하여 아이가 컴퓨터를 분석 시간에 사용하 는 것을 허락하였다. 아이는 컴퓨터에 중독되지 않고 자신의 학업과 교류를 위한 수단으로 사용했으며, 부재한 엄마의 관 심과 사랑 대신 자신의 내면 세계를 반영하는 대상으로서 컴퓨터를 사용했다. 아이는 인터넷 사이트에서 제공되는 시 각적, 언어적 자극을 통해 자신의 생각과 감정을 표현하고 재경험하였다. 이후 수년간 계속된 분석에서 인터넷상의 블 로그 방문, 웹툰 보기, 게임 등을 통하여 환아의 갈등과 역동 을 찾아내고 해결하는 과정이 이어졌다.

\section{결 론}

본 연구에서 IT 기기를 놀이치료에 활용 가능할 것인지에 대해 검토하였으나, 근거 중심적인 자료가 거의 없으므로 결 과 해석에 상당한 제약이 따른다. 즉, IT 기기를 정신치료에 도입한다는 것은 IT 기기의 치료적 기능과 안정성을 인정하 는 것이므로, 그렇게 하기 전에 충분한 검토가 필요하다. 현 단계에서는 너무도 빠르게 발전하며 생활 속으로 스며들고 있는 IT 기기의 문제를 생물학적으로 검증하기에는 역부족 이다. Freud가 카우치를 사용하기 위하여 미리 충분한 근거 를 마련한 것이 아닌 것처럼, IT 기기를 놀이치료에 활용하 는 것이 치료효과에 어떻게 작용할 것인가에 대한 충분한 근거중심의 자료가 부족하다고 해서 현대 사회 생활의 일부 를 굳이 치료현장에서 밀어낼 필요는 없을 것이다. 정신병리 이론도 관찰과 기술을 토대로 한 현상학을 기초로 발전하였 
고, Freud의 정신분석 이론이 증상관찰과 분석을 토대로 발 전한 것처럼 IT 기기의 놀이치료활용에 대한 근거는 치료현 장에서 치료경험과 관찰을 토대로 진행될 수 있을 것이며, 기기 사용에 대한 원칙도 정해야 할 것이다. 정신분석적 접 근의 기본 조건인 치료자와 환자 사이의 관계에서 치료적 상 호작용을 발전시키고 유지하기 위해 놀이치료 현장에서 IT 문화의 접목이 필요하다는 시대적, 문화적 요구에 대해 검토 와 연구가 필요한 시점이다.

\section{Conflicts of Interest}

The authors have no financial conflicts of interest.

\section{REFERENCES}

American Psychiatric Association. Diagnostic and Statistical Manual of Mental Disorders. 4th ed. Washington, DC: American Psychiatric Association;2013.

Brown S, Scharf MA, Bustos C, Chavira D, Stein MT. "Media addiction" in a 10-year-old boy. J Dev Behav Pediatr 2017;38 Suppl 1:S69S72.

Burton A. Design history and the history of toys: defining a discipline for the Bethnal Green Museum of Childhood. J Des Hist 1997;10:121.

Campbell K, Carpenter KL, Espinosa S, Hashemi J, Qiu Q, Tepper $\mathbf{M}$, et al. Use of a digital modified checklist for autism in toddlersrevised with follow-up to improve quality of screening for autism. J Pediatr 2017;183:133-139.e1.

Caruana N, McArthur G, Woolgar A, Brock J. Detecting communicative intent in a computerised test of joint attention. PeerJ 2017;5: e2899.

Chaudhry BM. Baby statistics: there is an App for that! Mhealth 2016;2: 23

Chung SJ, Colarusso C. The use of the computer and the internet in child psychoanalysis. Psychoanal Study Child 2012;66:197-223.

Chung WC, Cho YG, Kang JH, Park HA, Kim KW, Kang JH, et al. Lifestyle habits related to abdominal obesity in Korean adolescents. Korean J Fam Med 2010;31:547-554.

Council on Communications and Media. Media use by children younger than 2 years. Pediatrics 2011;128:1040-1045.

Cuperus AA, Laken M, van den Hout MA, Engelhard IM. Degrading emotional memories induced by a virtual reality paradigm. J Behav Ther Exp Psychiatry 2016;52:45-50.

Elhai JD, Dvorak RD, Levine JC, Hall BJ. Problematic smartphone use: a conceptual overview and systematic review of relations with anxiety and depression psychopathology. J Affect Disord 2017;207: 251-259.

Freud A. Indications for child analysis. Psychoanal Study Child 1945;1: 127-149.

Gensler D. Electronic and traditional ways of communicating and not communicating in adolescent psychotherapy. J Infant Child Adolesc Psychother 2011;10:402-410.

Goldberg I. Internet addiction disorder. Electronic message posted to research discussion list 1996 [cited 2011 Apr 20]. Available from: http://users.rider.edu/ suler/psycyber/supportgp.html.

Granic I, Lobel A, Engels RC. The benefits of playing video games. Am Psychol 2014;69:66-78.

Gustafson DH, Mc'Tavish FM, Chih MY, Atwood AK, Johnson RA, Boyle MG, et al. A smartphone application to support recovery from alcoholism: a randomized clinical trial. JAMA Psychiatry 2014;71: 566-572.
Hoffman A. Bridging the divide: using culture-infused counseling to enhance therapeutic work with digital youth. J Infant Child Adolesc Psychother 2013;12:118-133.

Jalink MB, Goris J, Heineman E, Pierie JP, Ten Cate Hoedemaker HO. Face validity of a Wii U video game for training basic laparoscopic skills. Am J Surg 2015;209:1102-1106.

Johnson E, Hervás R, Gutiérrez López de la Franca C, Mondéjar T, Ochoa SF, Favela J. Assessing empathy and managing emotions through interactions with an affective avatar. Health Informatics J 2016 Sep 30 [Epub]. https://doi.org/10.1177/1460458216661864.

Jones LM, Mitchell KJ, Finkelhor D. Trends in youth internet victimization: findings from three youth internet safety surveys 2000-2010. J Adolesc Health 2012;50:179-186.

Juvonen J, Gross EF. Extending the school grounds?--bullying experiences in cyberspace. J Sch Health 2008;78:496-505.

Karlsson E, Zingmark K, Axelsson K, Sävenstedt S. Aspects of self and identity in narrations about recent events: communication with individuals with Alzheimer's disease enabled by a digital photograph diary. J Gerontol Nurs 2017 Feb 2 [Epub]. https://doi.org/10.3928/ 00989134-20170126-02.

Kauer SD, Reid SC, Crooke AH, Khor A, Hearps SJ, Jorm AF, et al. Self-monitoring using mobile phones in the early stages of adolescent depression: randomized controlled trial. J Med Internet Res 2012;14:e67

Kenney EL, Gortmaker SL. United States adolescents' television, computer, videogame, smartphone, and tablet use: associations with sugary drinks, sleep, physical activity, and obesity. J Pediatr 2017;182: 144-149.

Kim MS, Moon HJ. A study on parental influences and analysis of young children's smart-phone usage. Korean J Hum Dev 2015;22:77-99.

Klein M. Narrative of a child analysis. London: Hogarth Press;1961.

Korea Internet and Security Agency. Survey on the internet usage on 2016 [updated 2017 Jan 31; cited 2017 Feb 10]. Available from: http:// isis.kisa.or.kr/board/?pageId $=060100 \&$ bbsId $=7$ \&itemId $=817$ \&pageIn $\operatorname{dex}=1$.

Kuss DJ, Griffiths MD. Internet and gaming addiction: a systematic literature review of neuroimaging studies. Brain Sci 2012;2:347-374.

Kwak YS. Play psychotherapy. J Korean Acad Child Adolesc Psychiatry 2000;11:161-178.

Lee YJ, Lee SI, Lee AR, Bahn GH, Choi TY, Kim JY, et al. Attitudes of psychiatrists towards smartphone usage of children and adolescents. J Korean Neuropsychiatr Assoc 2015;54:556-563.

Long J, Liu TQ, Liao YH, Qi C, He HY, Chen SB, et al. Prevalence and correlates of problematic smartphone use in a large random sample of Chinese undergraduates. BMC Psychiatry 2016;16:408

Macpherson K, Charlop MH, Miltenberger CA. Using portable video modeling technology to increase the compliment behaviors of children with autism during athletic group play. J Autism Dev Disord 2015;45:3836-3845.

Männikkö N, Billieux J, Kääriäinen M. Problematic digital gaming behavior and its relation to the psychological, social and physical health of Finnish adolescents and young adults. J Behav Addict 2015;4: 281-288.

National Information Society Agency. The survey on internet overdependence on 2015 [updated 2016 Jun 21; cited 2017 Feb 10]. Available from: http://nia.or.kr/site/nia_kor/ex/bbs/View.do?cbIdx $=65914$ $\& b c I d x=17132 \&$ parentSeq $=17132$.

Nes AA, van Dulmen S, Eide E, Finset A, Kristjánsdóttir OB, Steen IS, et al. The development and feasibility of a web-based intervention with diaries and situational feedback via smartphone to support self-management in patients with diabetes type 2. Diabetes Res Clin Pract 2012;97:385-393.

O'Keeffe GS, Clarke-Pearson K; Council on Communications and Media. The impact of social media on children, adolescents, and 
families. Pediatrics 2011;127:800-804.

Park JH, Hong JS, Han DH, Min KJ, Lee YS, Kee BS, et al. Comparison of QEEG findings between adolescents with attention deficit hyperactivity disorder (ADHD) without comorbidity and ADHD comorbid with internet gaming disorder. J Korean Med Sci 2017;32: 514-521.

Park MK, Ohm JA. Significance of play material experienced by children duringfree-choice activity time. Korean J Early Child Educ 2010;30:325-350

Park YS, Kim UC, Tak SY. Leisure activity and self-concept of adolescents in cyberspace: with specific focus on elementary school, middle school, high school and university students. Korean J Psychol Soc Issue 2011;17:81-113.

Pfaeffli L, Maddison R, Whittaker R, Stewart R, Kerr A, Jiang Y, et al. A mHealth cardiac rehabilitation exercise intervention: findings from content development studies. BMC Cardiovasc Disord 2012;12:36.

Plowman L, McPake J. Seven myths about young children and technology. Child Educ 2013;89:27-33.

Plowman L, Stephen C, McPake J. Growing up with technology: young children learning in a digital world. London: Routledge;2010. p.821.

Prensky M. Digital natives, digital immigrants part 1. On Horiz 2001;9: $1-6$

Pujol J, Fenoll R, Forns J, Harrison BJ, Martínez-Vilavella G, Macià D, et al. Video gaming in school children: How much is enough? Ann Neurol 2016;80:424-433.

Roh JH, Lee J, Koh MS, Kim YJ, Seol IJ, Moon JH. The current state and changes in smart device usage and utilization level in preschool children. J Korean Child Neurol Soc 2016;24:157-163.

Roseberry S, Hirsh-Pasek K, Golinkoff RM. Skype me! Socially contingent interactions help toddlers learn language. Child Dev 2014;85: 956-970.

Rotimi O, Orah N, Shaaban A, Daramola AO, Abdulkareem FB. Remote teaching of histopathology using scanned slides via skype between the United Kingdom and Nigeria. Arch Pathol Lab Med 2017; 141:298-300

Saleh F, Grudzinskas A, Judge A. Adolescent sexual behavior in the digital age: considerations for clinicians, legal professionals and educators. New York: Oxford University Press;2014. p.121-129.

Selkie EM, Fales JL, Moreno MA. Cyberbullying prevalence among US middle and high school-aged adolescents: a systematic review and quality assessment. J Adolesc Health 2016;58:125-133.

Sosa AV. Association of the type of toy used during play with the quantity and quality of parent-infant communication. JAMA Pediatr 2016; 170:132-137.

Strasburger VC, Hogan MJ, Mulligan DA, Ameenuddin N, Christakis DA, Cross C, et al. Children, adolescents, and the media. Pediatrics 2013;132:958-961.

Student Health Service (Department of Health, the Government of the Hong Kong Special Administrative Region). Healthy use of internet and electronic screen products [updated 2014 Jul 17; cited 2015 Aug 24]. Available from: http://www.studenthealth.gov.hk/english/ internet/report/files/e_report.pdf.

Subrahmanyam K, Greenfield P. Online communication and adolescent relationships. Future Child 2008;18:119-146.

Subrahmanyam K, Šmahel D. Digital youth: the role of media in development. New York: Springer;2011.

Tapscott D. Growing up digital: the rise of the net generation. New York: McGrawHill;1998.

Torous J, Staples P, Shanahan M, Lin C, Peck P, Keshavan M, et al. Utilizing a personal smartphone custom app to assess the Patient Health Questionnaire-9 (PHQ-9) depressive symptoms in patients with major depressive disorder. JMIR Ment Health 2015;2:e8.

Tworus R, Szymanska S, Ilnicki S. A soldier suffering from PTSD, treated by controlled stress exposition using virtual reality and behavioral training. Cyberpsychol Behav Soc Netw 2010;13:103-107.

van Oosten JM, Vandenbosch L. Sexy online self-presentation on social network sites and the willingness to engage in sexting: a comparison of gender and age. J Adolesc 2017;54:42-50.

Vandermeer J, Beamish W, Milford T, Lang W. iPad-presented social stories for young children with autism. Dev Neurorehabil 2015;18: 75-81.

Watts S, Mackenzie A, Thomas C, Griskaitis A, Mewton L, Williams A, et al. CBT for depression: a pilot RCT comparing mobile phone vs. computer. BMC Psychiatry 2013;13:49.

Whang LS, Chang G. Lifestyles of virtual world residents: living in the on-line game "lineage". Cyberpsychol Behav 2004;7:592-600.

Winnicott DW. Playing and reality. London: Tavistock Publications;1971. p.38-52.

Zelnick L. The computer as an object of play in child treatment. J Infant Child Adolesc Psychother 2005;4:209-217. 